\title{
A COMPARATIVE ANALYSIS ON INTERNATIONAL REFUGEE LAW AND TEMPORARY PROTECTION IN THE CONTEXT OF TURKEY
}

\author{
DIKRAN M. ZENGINKUZUCU ${ }^{1}$
}

\begin{abstract}
The Syrian civil war prompted a large number of people to flee their country and seek asylum in other countries, making Turkey a leading host country with around 3.6 million of asylum seekers. Syrian asylum seekers in Turkey are under temporary protection regime. This article examines Turkish temporary protection regime in comparison with international protection standards and human rights law, especially with the UNHCR Guideline and European Union legislation on temporary protection and European Court on Human Rights judgements. In this respect, this article argues that Turkish legislation has met the fundamental requirements of international protection law and standards, however, still needs to be improved in some crucial areas. In this regard, the international protection law and the difference between the status of refugee and temporary protection is explored. Subsequently, declaration of temporary protection in case of a mass-influx, the rights and freedoms covered under temporary protection, non-refoulement principle and termination of temporary protection regime under Turkish Temporary Protection Regulation are discussed and compared with the international standards. Finally, some conclusions and recommendations for the improvement are deduced from this discussion.
\end{abstract}

Keywords: Turkish Law on Foreigners and International Protection, Turkey's asylum system, Turkish temporary protection regime, Syrian asylum seekers in Turkey, International protection.

Summary: 1. Introduction. 2. History of International Protection Law. 3. The Core of International Protection Law. 3.1. Definition of the term 'refugee'. 3.2. Negative protection of human rights. 3.3. Principle of 'non-Refoulement'. 4. International Protection and Temporary Protection. 4.1. Scope of Temporary Protection. 4.2. Obligations of the host States towards Persons under Temporary Protection. 4.3. Implementation of the Obligations in Turkey and Rights of Asylum seekers under Temporary Protection. 4.4. Non-refoulement. 4.5. Termination of Temporary Protection. 5. ConcLusion.

\section{INTRODUCTION}

One of the most crucial and increasingly worsening problem of international society is still the situation of those people who are forced to immigrate because of wars, religious or ethnic conflicts, political pressures, economic demolitions, climate

\footnotetext{
1 Assoc. Prof. Dr. Istanbul Esenyurt University, Faculty of Business and Administrative Sciences, Department of Political Science and International Relations (dikranzenginkuzucu@esenyurt.edu.tr). https://orcid.org/0000-0002-4521-4868.

In the first half of the $20^{\text {th }}$ century, the human history witnessed two ever most violent and cruel war and millions of defenceless people have become homeless. Hannah Arendt (1976), one of the most impressive thinkers of the previous century, was highly amazed when she perceived about unmerciful treatment that the refugees had faced after World War I. These unfortunate people had lost their human rights, perceived and allegedly claimed as inalienable and untouchable. Famous Italian thinker Giorgio Agamben (1998) tried
} 
change and environmental diseases or others. As of December 2017, the United Nations High Commissioner for Refugees (UNHCR, (2018) reported that 74.8 million people worldwide are seeking resettlement. Turkish Directorate General of Migration Management (TDGMM, (2020), on the other hand, reports that there are 3,643,769 Syrian nationals hosted in Turkey as of 6 January 2021. In this article, first, the history and context of the international protection law will be evaluated. Secondly, I will argue that international refugee law consists of three pillars. Furthermore, test of three pillars will be applied to international standards and Turkish legislation on temporary protection. Finally, I will conclude with some suggestions on the improvement of the system.

\section{History of International Protection Law}

The efforts for concluding an international legal instrument for the status and protection of refugees has first introduced in the era of the League of Nations to provide them with a legal status, ensure appropriate behaviour against them and protect their human rights. However, it has been unfortunately far from establishing a permanent and satisfying protection system (UNHCR, 2011a).

As the refugee problem accelerated after World War II, one of the first task of the United Nations (UN) General Assembly was the adoption of the Statute of UNHCR on 14 December $1950^{2}$. As soon as the office of UNHCR was established as of 1 January $1951^{3}$, a Conference of Plenipotentiaries took place in Geneva, Switzerland on 25 July 1951 and adopted the text of a Convention defining standards for the treatment of refugees on 28 July 1951 (UNHCR, (1951). As a result, the Convention relating to the Status of Refugees (hereinafter 1951 Convention) was adopted by the United Nations (UN) General Assembly with the status of the UNHCR on 14 December 1951 and opened to the signature of the member States. The 1951 Convention, defining the category of 'refugee' and setting down their rights as well as the obligations of States, entered into force on 22 April 1954. Indeed, Art 1/A (2) of the 1951 Convention initially restricted its applicability to persons who had become refugee due to the events occurring before 1 January 1951. The Convention also introduced an alternative of geographical limitation such as each Contracting State shall make a declaration specifying if it would apply the 1951 Convention for the events occurring only inside Europe or everywhere. A Protocol relating to the status of refugees signed on 31 January 1967 and entered into force on 4 October 1967 (hereinafter 1967 Protocol) broadened the applicability of the 1951 Convention by eliminating temporal and geographical limitations unless a Contracting

to clarify Hannah Arendt's confusion with reference to Foucault's arguments. In the modern era, where the human being has become the subject of politics, people cannot enjoy their rights connected with the sovereign power - or national sovereignty- without possessing a 'tie of citizenship', which attaches the individual to the 'nation'. However, if 'human rights' were a formulation for all human beings without limitation of time or space, the groups who should enjoy these rights, should be those who were wronged the most, namely refugees.

${ }^{2}$ UN GA Res. 319 (IV), 3 December 1950.

${ }^{3}$ UN GA Res. 428 (V), 14 December 1950 Annex. 
State might maintain a declaration about geographical limitation made under Art 1/B (1) of the 1951 Convention. ${ }^{4}$ As of 25 August 2018, 145 States are party to the 1951 Convention and the 1967 Declaration. Turkey as well is a Contracting Party to the 1951 Convention $^{5}$ and the 1967 Protocol. $^{6}$ Turkey made a declaration under Art 1/B of the 1951 Convention according to which it applies the Convention only to persons who have become refugees because of 'events occurring in Europe before 1 January 1951'. By a declaration with the instrument of accession for the 1967 Protocol, Turkey maintained the geographical limitation on the 1951 Convention.

Turkey adopted its legislation on international protection of refugees under the Law on Foreigners and International Protection (LFIP). ${ }^{7}$ It is obvious that LFIP is drafted with the suggestions and promotions of the European Union (EU) as a part of Turkey-EU membership negotiations as a part of EU enlargement policy (EC, 2013a,b). Part three of the LFIP codifies types of international protection, general procedures on applications, administrative reviews and judicial appeal, exclusion, termination and cancellation of international protection, rights and obligations as well as the status of temporary protection. Hereafter, LFIP and related Turkish legislation will be assessed in terms of international protection law (Ineli-Ciger, 2014, p. 28-36; Rygiel, Baban \& Ilcan, 2016, p. 315-320; Dardagan Kibar, 2013, p. 109-128; Soykan, 2012, p. 38-47; Acikgoz \& Aniker, 2014; Dalkiran, 2016; AIDA, 2020).

\section{The Core of International Protection Law}

The essentials and three pillars of 1951 Convention as amended by 1967 Protocol$^{8}$, which constitute the basis of international refugee law, may be cited as follows:

- Definition of the term 'refugee' and its scope

- Negative protection of the rights and freedoms of refugees

- Principle of 'Non-Refoulement'

\subsection{Definition of the term 'refugee'}

Art 1/A (2) of the 1951 Convention gives a clear definition of the term 'refugee' which is widely accepted in international law. That is; any person who:

\footnotetext{
${ }^{4}$ Art 1 (3) of the 1967 Protocol is as follows;

'The present Protocol shall be applied by the States Parties hereto without any geographic limitation, save that existing declarations made by States already Parties to the Convention in accordance with article 1 B (1) (a) of the Convention, shall, unless extended under article 1 B (2) thereof, apply also under the present Protocol.'

${ }^{5}$ Signed: 24 August 1951, OG no 10898 dated 5 September 1961. Ratification: 30 March 1962.

${ }^{6}$ Council of Ministers Decree no 6/10266 dated 1 July 1968, OG no 12968 dated 5 August 1968. Accession: 31 July 1968.

${ }^{7}$ Law no 6458 dated 4 April 2013, OG 28615 dated 11 April 2013.

${ }^{8}$ Hereinafter 1951 Convention means 1951 Convention as amended by 1967 Protocol unless otherwise stated.
} 
'[O]wing to well-founded fear of being persecuted for reasons of race, religion, nationality, membership of a particular social group or political opinion, is outside the country of his nationality and is unable or, owing to such fear, is unwilling to avail himself of the protection of that country; or who, not having a nationality and being outside the country of his former habitual residence as a result of such events, is unable or, owing to such fear, is unwilling to return to it.'

In this respect, the 'refugee' is a person who has been forced to quit the country of his nationality or his former habitual country and is unable or unwilling to return to it because of a well-founded fear of being persecuted due to his or her;

- race

- religion

- nationality

- membership of a social group

- political opinions

The 1951 Convention gives a closed-ended five grounds, in other words 'five sins ${ }^{\prime 9}$ against humanity, of seeking asylum as 'refugee' in a Contracting State. In this term, for example, the immigrants who are the victims of an environmental disaster are not entitled to recourse to the status of refugee (Black, 2001). However, it does not certainly inhibit a country to make a larger definition containing at minimum the abovecited five ground.

Furthermore, the status of refugee is an individual status and needs to be assessed and recognised on a case-by-case basis by the host State. There is no recognition or acquisition in-group of the status of refugee in international law. In Asylum case, International Court of Justice (ICJ) explained that; 'international law does not recognize any rule of unilateral and definitive qualification by the State granting diplomatic asylum' and 'A decision to grant diplomatic asylum involves a derogation from the sovereignty of that State... Such a derogation from territorial sovereignty cannot be recognized unless its legal basis is established in each particular case'. ${ }^{10}$ In these excerpts, the ICJ reconfirmed that the granting of territorial asylum is a right, not an obligation of States, and it is possible, in principle, to enquire whether the potential protective State is willing to recognise the individual as a refugee case by case (Värk, 2012). Therefore, this is not an available procedure and obligation for the States to cope with the mass-influx.

LFIP, on the other hand, formulates three status of 'refugee', namely refugees, conditional refugees and subsidiary protection. Art 61 describes 'refugees' as follows:

\footnotetext{
${ }^{9}$ Not being a legal term, the expression 'five sins' is used by the author to refer to the crimes committed by the States as per referred by the 1951 Convention, namely discrimination, pressure and condemnation based on racial, religious, nationality or ethnicity, membership to a social group and political opinions, which give rise to millions around the World becoming refugees and asylum seekers.

${ }^{10}$ Asylum case, Colombia v. Peru, Judgement of 20 November 1950, ICJ Reports (1950), 274-275.
} 
'A person who as a result of events occurring in European countries and owing to well-founded fear of being persecuted for reasons of race, religion, nationality, membership of a particular social group or political opinion, is outside the country of his citizenship and is unable or, owing to such fear, is unwilling to avail himself or herself of the protection of that country; or who, not having a nationality and being outside the country of his former residence as a result of such events, is unable or, owing to such fear, is unwilling to return to it...'

LFIP obviously borrows the definition of the 1951 Convention with a geographical limitation in accordance with its declaration to the Convention. Thus, Turkey undertakes to grant refugee status for those who have left their country in Europe forcibly for one of the above-cited five reasons.

Art 62 constitutes a transitory regime, namely conditional refugees, for asylum seekers from outside European countries due to five cited reasons. Those people are permitted to reside in Turkey temporarily until they are resettled in a third country.

Art 63, furthermore, is granting a 'subsidiary protection', which is a complementary protection regime, to a foreigner or a stateless person, who could be qualified neither as a refugee nor as a conditional refugee, however who would, 'if returned to the country of origin or country of [former] habitual residence:

a) be sentenced to death or face the execution of the death penalty;

b) face torture or inhuman and degrading treatment or punishment;

c) face serious threat to himself or herself by reason of indiscriminate violence in situations of international or nationwide armed conflict'.

Art 1/C of the 1951 Convention addresses four bases for the cessation of the status of refugee as;

a) re-availment of national protection;

b) re-acquisition of nationality;

c) acquisition of a new nationality; and

d) re-establishment in the State of origin.

This formal cessation depends on voluntariness and intention of the refugee, which requires careful application of the procedures by the competent authorities.

Art 1/C (5\& 6) continues with the cessation condition when 'the circumstances in connection with which one has been granted the status of refugee have ceased to exist and the refugee continues to refuse to avail himself of the protection of the country of his nationality' or 'if he is stateless return to the country of his formal habitual residence'. This is an involuntary situation prosecuted notwithstanding the intention of the refugee and depends on the interpretation of the current situation in the corresponding country. Even though Contracting States have the authority to invoke Art 1/C (5 \& 6), it is more convenient to make or follow an international determination on the situation in 
the corresponding country. In such a circumstance, for example, the UNHCR may be expected to make a declaration that 'its competence ceases to apply regarding persons falling within situations spelled out in the Statute' (Fitzpatrick \& Bonoan, 2003). Art 85/1 of the LFIP requotes mot-à-mot Art 1(C) of the 1951 Convention. For the interpretation of the cessation of the circumstances in the former country Art 85/2 provides that: 'In the assessment under subparagraphs (d) and (e) of the first paragraph, it shall be considered whether the circumstances upon which the status was granted no longer apply or have changed significantly and permanently'.

Art $1 / \mathrm{F}$ of the 1951 Convention states that the international protection as determined in the mentioned Convention shall not be applied to 'any person who has committed a crime against peace, a war crime or a crime against humanity as described in international instruments"11, a serious non-political crime or has been guilty of acts contrary to the principles and purposes of the UN Charter. LFIP Art 64 excludes those persons from international protection.

\subsection{Negative protection of human rights}

Human rights may be described briefly the rights alienable and untouchable of every human being regardless his/her nationality, race, gender, language or religious, social, ethnical or other attributes, without which a human being may not be supposed to have an honourable life. International human rights law as well as humanitarian law prohibit the limitation of some core rights even in war or other extraordinary times. ${ }^{12}$ Those rights and freedoms are mainly the right to life, prohibition of torture and degrading treatment or punishment, prohibition of slavery, freedom of thought, conscience and religion, and no punishment without law. In this respect, every refugee or stateless person is entitled to above cited rights and freedoms without any exceptions wherever they reside.

Furthermore, the 1951 Convention provides in Art 7(1) that; 'except where this Convention contains more favourable provisions, a Contracting State shall accord to refugees the same treatment as in accorded to aliens generally'. In this respect, a refugee is entitled at minimum to the same rights and treatments as an alien who is deemed as lawfully staying in the territories of the Contracting State. On the other hand, the 1951 Convention provides the refugee with some rights equal to a national. In this respect, the 1951 Convention enumerates the rights and freedoms of refugees in three categories (Table 1):

\footnotetext{
${ }^{11}$ The crimes under the jurisdiction of International Criminal Court established under Rome Statute (2002). Art 89/1 of the Rome Statute requires Contracting Parties to arrest and surrender persons upon the request of the Court.

${ }^{12}$ UN International Covenant on Civil and Political Rights (1966) Art 4; European Convention on Human Rights (1950) Art 15; For the prohibition in war time see Legality of the Threat or Use of Nuclear Weapons, Advisory Opinion of 8 June 1996, ICJ Reports 1996, 256; 'The Court observes that the protection of the International Covenant on Civil and Political Rights does not cease in times of war, except by operation of Art 4 of the Covenant whereby certain provisions may be derogated from in a time of national emergency.'
} 
Table 1. Rights and freedoms in 1951 Convention

\begin{tabular}{|l|l|l|}
\hline $\begin{array}{l}\text { As favourable as possible - } \\
\text { not less favourable than that } \\
\text { accorded to aliens }\end{array}$ & As a national of the country & Special regulations \\
\hline Acquiring property (Art. 13) & $\begin{array}{l}\text { Freedom from discrimination } \\
\text { (Art. 3) }\end{array}$ & Administrative assistance (Art. 25) \\
\hline Housing (Art. 21) & Freedom of Religion (Art. 4) & Identity Papers (Art. 27) \\
\hline Right to association (Art. 15) & $\begin{array}{l}\text { Intellectual and industrial } \\
\text { property rights (Art. 14) }\end{array}$ & Travel documents (Art. 28) \\
\hline Labour rights (Art. 17) & Access to justice (Art. 16) & Transfer of assets (art 30) \\
\hline $\begin{array}{l}\text { Right to education - high } \\
\text { education (Art. 22/2) }\end{array}$ & $\begin{array}{l}\text { Right to education - fundamental } \\
\text { education (Art. 22/1) }\end{array}$ & $\begin{array}{l}\text { Exception from prosecution for } \\
\text { unlawfully entrance in the country } \\
\text { (Art. 31) }\end{array}$ \\
\hline $\begin{array}{l}\text { Right to settlement and travel } \\
\text { (Art. 26) }\end{array}$ & Rationing (Art. 20) & Naturalisation (Art. 34) \\
\hline & Social aid (Art. 23) & \\
\hline & Social security (Art. 24) & Fiscal charges (Art. 29) \\
\hline
\end{tabular}

Some rights and freedom that have relation with sovereignty rights such as acquiring immovable or right relating political activities such as right to association are limited, whereas the rights and freedoms which are firmly attached to one's personality and existence such as freedom from discrimination, freedom of religion, intellectual property rights, right to fundamental education and some social rights, which are assumed that one needs to survive in an human condition shall be equal to a national of the country.

LFIP itself regulates the right of labour (Art 89/4), right to fundamental education (Art 89/1), social assistance (Art 89/2), freedom to settlement and travel (Art 82), identity papers (Art 83) and travel documents (Art 84) in accordance with the 1951 Convention.

As amended in $2014^{13}$, Turkish Constitution Art 90 (5) provides that:

'International agreements duly put into effect have the force of law... In the case of a conflict between international agreements, duly put into effect, concerning fundamental rights and freedoms and the laws due to differences in provisions on the same matter, the provisions of international agreements shall prevail'.

In this respect, if there is an indeterminate area or gap in domestic legislation on international protection or even there is conflict between the 1951 Convention and domestic legislation, the regulations of the 1951 Convention prevail and are directly applicable in the case of a refugee as described in Art 1 of the 1951 Convention with the declaration on geographical limitation of Turkey. On the other hand, it will be more

\footnotetext{
${ }^{13}$ Law no 5170 dated 7 May 2014, OG 25469 dated 22 May 2014.
} 
appropriate that LFIP codifies itself especially the rights and freedoms of refugees, which shall be equal to a national and other special regulations for refugees recognised in the 1951 Convention.

\subsection{Principle of 'non-Refoulement'}

One of the main protection under the umbrella of international refugee law is the principle of 'non-refoulement' as it is provided in Art 33/1 that preclude Contracting States from returning a refugee to the countries where he or she may face persecution or execution due to his/her race, religion, nationality, membership of a social group or political opinion. The scope of Art 33/1 of the 1951 Convention covers a person who already is granted refugee status by a Contracting State. Moreover, refugees are free of 'refoulement' only due to threat to his/her life or freedom due to the 'five sins'. On the other hand, Art 33/2 excludes a refugee who has committed a serious crime or act that constitutes reasonable grounds for regarding as a danger to the security of the host country. Art 33/2 seems to allow host States to deport and remove refugees to their former country even if there is a danger as described in Art 33/1. Although it is argued that the non-refoulement principle as provided by Art 33 of the 1951 Conventions shall not cover the possibility of mass migrations across frontiers and, it is not usually practical for a country overwhelmed by a mass influx of refugees to engage in this kind of detailed, case-by-case analysis of risks to its own well-being. Governments therefore wanted the assurance that in truly exceptional circumstances, they could engage in peremptory refoulement to the extent truly necessary to protect their most critical national interests (Hathaway, 2005, p. 357).

LFIP make a broader regulation than the 1951 Convention with respect to the principle of 'non-refoulement'. Art 55 of the LFIP prohibits the removal of foreigners in general;

a) when there are serious indications to believe that they shall be subjected to the death penalty, torture, inhuman or degrading treatment or punishment in the country to which they shall be returned to;

b) who would face risk due to serious health condition, age or, pregnancy in case of travel;

c) who would not be able to receive treatment in the country to which they shall be returned while undergoing treatment for a life-threatening health condition;

d) victims of human trafficking, supported by the victim's assistance programme;

e) victims of serious psychological, physical or sexual violence, until their treatment is completed.

LFIP provides that the assessment of the persons within the scope of the principle of 'non-refoulement' shall be done on case-by-case basis and these persons may be asked to reside at a given address and report their presence to the authorities. Art 46/c of the LFIP provides them with a humanitarian permit by the governorates with a maximum renewable one-year period. On the other hand, the principle of 'non-refoulement' in Turkish legislation is wider than refugee law. Turkey is a Party to the European Convention 
on Human Rights (ECHR) and is bound by the definition and application of the principle of 'non-refoulement' in the ECHR. In Ahmed v. Austria case ${ }^{14}$, Sharif Hussein Ahmed who is a Somali national, left Somalia and reached the Vienna Airport in October 1990, after which he requested a refugee status by reason of fear of being arrested and executed because his relatives were members and sympathizer of United Somali Union, an opposite political group. He was granted refugee status in 1991. However, the Graz Regional Court sentenced him to two and a half years imprisonment for attempted robbery in 1993 and as a result, the Graz Federal Court ordered the forfeiture of his refugee status in 1994. In April 1995, the Federal Refugee Office declared the proposed expulsion of the applicant lawful, even if he risked persecution in Somalia, because of his tendency toward aggression. The applicant's appeal was dismissed. European Court of Human Rights (ECtHR) considered the application in terms of Art 3, of the ECtHR relating right to life as well as Art 5 relating right to liberty and security and Art 13 relating right to an effective remedy. The Court agreed that the applicant's deportation to Somalia would lead to the applicant facing a serious risk of treatment contrary to Art 3. Therefore, his deportation would constitute a breach of Art 3 if he faced a serious risk of being subjected there to torture or inhuman or degrading treatment, and that this conclusion on the absolute nature of Art 3 was not invalidated by the applicant's criminal conviction or the lack of State authority in Somalia at the time. In this respect, ECHR provides that Contracting States shall observe the right to life and right to be free of torture and degrading treatment of every person within its jurisdiction without derogation and this observance includes the principle of 'non-refoulement'. The judgement of the Court is based on the rule of non-derogation in all cases and situations from the essential human rights as right to life and prohibition of torture and degrading treatment. ${ }^{15} \mathrm{UN}$ International Covenant on Civil and Political Rights also contains the same rule of non-derogation from rights to life and prohibition of torture and degrading treatment. In this respect, the same obligation of 'non-refoulement' shall be valid for all Party States to the UN Covenant. UN Human Rights Committee and UN Committee Against Torture also, in their turn, perform a test of the rights to life and prohibition of torture and degrading treatment for the communication before it on the decisions of deportation. ${ }^{16}$

A further consideration on the principle of 'non-refoulement' which broadening its application beyond the formulation of Art 33 of the 1951 Convention is that the principle of 'non-refoulement' attained jus cogens nature in international law and have been accepted

\footnotetext{
${ }^{14}$ Ahmed v. Austria, Application no 25964/94, Judgement of 17 December 1996, par 46.

${ }^{15}$ Also see. Soering v. UK, Application no 14038/88, Judgement of 7 July 1989, par. 111; Chahal v. UK, Application no 22414/93, Judgement of 15 November 1996, par. 80; H.L.R. v. France, Application no 24573/94, Judgement of 29 April 1997, Dissenting Opinion of Judge Pekkanen, par. 4. Vilvarajah and others v UK, Application no 13163/87,13164/87, 13165/ 87, 13447/87, 13448/87, Judgement of 30 October 1991; Mamatkulov and Askarov v Turkey, Application no 46827/99, 46951/99, Judgement of 4 February 2005 .

${ }^{16}$ Human Rights Committee, General Comment No. 31 [80], The Nature of the General Legal Obligation Imposed on States Parties to the Covenant. 29 March 2004, par.12; Human Rights Committee, A.H.S. $v$ Denmark, Application no 2419/2014, 28 March 2017, par. 11.2; Committee Against Torture AT, G.R.B.v. Sweden, Application no 083/1997, 15 May 1998), par. 6.7.
} 
by the international community as a whole (Riyanto, 2010: 742-749; Costello \& Foster, 2016: 272-327. Allain, 2001; Goodwin-Gill \& McAdam, 2007). On the other hand, some scholars argue that non-refoulement principle constitutes a part of customary international law (Bruin \& Wouters, 2003), whereas others claim that the non-derogatory status of the prohibition of torture raises a peremptory character to the principle of non-refoulement (Dugard \& Van den Wyngaert, 1998, p. 198; Lauterpacht \& Bethlehem, 2003, p. 163).

\section{International Protection and Temporary Protection}

The protection regime established by the 1951 Convention has some inconsistencies that greater number of States are looking for implicit withdrawal of their duties and obligations under international refugee law and dramatically fewer asylum seekers today have access to available protection. Indeed, a restrictive and selective refugee policy is not a new trend in western countries, which try to keep problems away from their borders and expect the rest of the world to play host to refugees (Chimni, 2000). Another fundamental shortcoming of the international refugee law is the individuated state responsibility under which the state responsibility towards refugees is based primarily on the relative ability of the States to control their borders (Hathaway, 2001). A further issue is arising from the individualistic character of the refugee process, which may render the process not applicable, at least effectively and duly, in a mass influx. In addition, because of the closeended definition of refugee in international law, victims of complex contemporary social and political problems as well as environmental disasters may fall outside international protection. In this respect, temporary protection has been considered as an exceptional measure and a pragmatic tool to address particular situations of large-scale influx where national asylum systems may be overwhelmed (UNHCR, (2000).

Temporary protection regime has no common and agreed definition under international law and has different meanings and applications depending on the context and countries. Most frequently, it is understood as a short-term emergency response to a 'mass influx' of asylum seekers to diminish the gravity of the circumstance where it is difficult to handle the mass movement and make an effective distinction between asylum seekers and others (Edwards, 2012). Thus, two faces of temporary protection are as follows: First, in a positive way, expand emergency humanitarian assistance and ameliorate the situation of masses who unfortunately do not fall into the scope of the 1951 Convention. Secondly, temporary protection may be suspiciously used by some countries as a toll of displacing the regime and protection under international refugee law and avoiding from their corresponding responsibilities (Fitzpatrick, 2000).

As a result of several mass influx caused by armed conflicts as well as social and political disturbances, Organization of African Union (OAU) expanded the definition of 'refugee' in Art I/2 of OAU Convention governing the Specific Aspects of Refugee Problems in Africa ${ }^{17}$ as follows:

\footnotetext{
${ }^{17}$ Adopted on 10 September 1969 by the Assembly of Heads of State and Government. CAB/LEG/24.3. Entered into force on 20 June 1974.
} 
'Every person who, owing to external aggression, occupation, foreign domination or events seriously disturbing public order in either part or the whole of his country of origin or nationality, is compelled to leave his place of habitual residence to seek refuge in another place outside his country of origin or nationality'.

Another massive flight has been witnessed in 1970's and 1980's from Southeast Asia country in political and social disruptions. Especially in the flows from Vietnam, Laos and Cambodia, there were many persons falling within the scope of the 1951 Convention, whereas many others seeking to escape with fear and anxiety of the situation in their home country torn by armed conflicts (Fitzpatrick, 2000). In a similar way, Organisation of American States declared that; 'in view of the experience gained from the massive flows of refugees in the Central American area, it is necessary to consider enlarging the concept of a refugee, bearing in mind, as far as appropriate and in the light of the situation prevailing in the region' ${ }^{18}$ In the early 1990's, European States found themselves in an unusual flow towards their borders from former Yugoslavia. European countries responded this migration crisis by favouring temporary protection in place of granting refugee status and durable asylum and many countries introduced their temporary protection policies and instruments (Mansouri, Leach, \& Nethery, 2009, p. 136) and adopted Minimum Standards for Giving Temporary Protection in the Event of a Mass Influx. ${ }^{19}$ The ongoing civil war in Syria resulted with mass influx to neighbour countries as well as Turkey, having the longest border with Syria. Consequently, Turkey welcomed millions of Syrian citizens into its territory. As mentioned above, Turkey made a declaration to the 1951 Convention and put a geographical limitation. Therefore, Turkish legislation does not recognise asylum seekers moved because of events occurring outside Europe as refugee. In this circumstance, Turkey allowed the mass influx from Syria in the cadre of temporary protection and adopted a Temporary Protection Regulation (TPR) in $2014^{20}$ in accordance with Art 91 of the LFIP.

It is mentioned above that the absence of an international definition and regulation, the extension of temporary protection regime compromises a hidden risk of arbitrariness and abuse in a way to narrow the rights of asylum seeker and forced migrants. In this respect, corresponding efforts towards defining and establishing minimum treatment standards towards displaced persons under temporary protection has been included in the agenda of several institutions. The EU has established a Common European Asylum System (CEAS) which is strengthened in 2020 (EU, 2020, p. 105). The EU Directive on common procedures for granting and withdrawing international protection ${ }^{21}$ recognizes

\footnotetext{
${ }^{18}$ Cartagena Declaration dated 22 November 1984 Art III/3.

${ }^{19}$ European Union: Council of the European Union, Council Directive 20 01/55/EC of 20 July 2001 on Minimum Standards for Giving Temporary Protection in the Event of a Mass Influx of Displaced Persons and on Measures Promoting a Balance of Efforts Between Member States in Receiving such Persons and Bearing the Consequences Thereof, 7 August 2001, OJ L.212/12-212/23; 7.8.2001, 2001/55/EC [online]. Available at: http://www.refworld.org/docid/3ddcee2e4.html (Accessed 28 August 2018).

${ }^{20}$ Council of Ministers Decree no 2014/6883 dated 13 October 2014, OG no 29153 dated 22 October 2014. ${ }^{21}$ European Union: Council of the European Union, Council Directive 2013/32/EU of 26 June 2013 on common procedures for granting and withdrawing international protection (recast), OJ L.180/60; 29.6.2013 [online]. Available at: https://eur-lex.europa.eu/legal-content/EN/TXT/PDF/?uri=CELEX:32013L0032\&from=en (Accessed 18 March 2021).
} 
refugee and subsidiary protection status for asylum seekers in conformity with Art 1 of the 1951 Convention. Furthermore, the Council of EU adopted a Directive (hereinafter EC Directive) on minimum standards for giving temporary protection in 200122. Furthermore, the UNHCR published a 'Guideline on Temporary Protection or Stay Arrangements' (hereinafter Guideline) in 2014 (UNHCR, (2014). The European Council (EC) proclaimed that 'cases of mass influx of displaced persons who cannot return to their country of origin have become more substantial in Europe in recent years. In these cases, it may be necessary to set up exceptional schemes to offer them immediate temporary protection' and 'it is therefore necessary to establish minimum standards for giving temporary protection in the event of a mass influx of displaced persons and to take measures to promote a balance of efforts between the Member States in receiving and bearing the consequences of receiving such persons' (EC Directive, Preamble 2 and 8). The European Council further provided that; 'this temporary protection should be compatible with the Member States' international obligations as regards refugees' (EC Directive, Preamble 10). The UNHCR, on the other hand, set forward the aim of its Guideline as 'to guide and assist Governments in the development of Temporary Protection or Stay Arrangements (TPSA's) as responses to humanitarian crises and complex or mixed population movements, particularly in situations where existing responses are not suited or adequate'.

In this regard, we may deduce that developing international understanding on temporary protection in international arena is to deliver emergency humanitarian assistance and expand the coverage of at least minimum standards of international protection to those people who have been forced to leave their country and seek asylum or temporary sanctuary in another country because of violence or indispensable reasons they had faced in their home country. In this term, we may assume that the aim of temporary protection is to widen the scope of international protection and cover those people who do not fall into the frame of the 1951 Convention until they are qualified for granting 'refugee' status or their return. As a result, temporary protection is expected to provide a protection at a satisfactory level of the three pillars of international refugee law. Thereafter, we will consider the coverage of temporary protection regime in the context of three pillars of international refugee law.

\subsection{Scope of Temporary Protection}

According to Art 2 of the EC Directive, the subjects of temporary protection regime, 'displaced persons' in other words, are:

'[T]hird-country nationals or stateless persons who have had to leave their country or region of origin, or have been evacuated, in response to an appeal by international organisations, and are unable to return in safe and durable conditions because of the situation prevailing in that country, who may fall within the scope of Art 1A of the Geneva Convention or other international or national instruments giving international protection, in particular:

${ }^{22}$ See fn 19. 
(i) persons who have fled areas of armed conflict or endemic violence;

(ii) persons at serious risk of, or who have been the victims of, systematic or generalised violations of their human rights'

As referred in paragraph 9 of the Guideline, the UNHCR, in its turn, encourages TPSA's particularly as a suitable response to:

(i) large-scale influxes of asylum-seekers or other similar humanitarian crises;

(ii) complex or mixed cross-border population movements, including boat arrivals and rescue at sea scenarios;

(iii) fluid or transitional contexts [e.g., at the beginning of a crisis where the exact cause and character of the movement may be uncertain, or at the end of a crisis, when the motivation for departure may need further assessment]; and

(iv) other exceptional and temporary conditions in the country of origin necessitating international protection and which prevent return in safety and dignity.'

Both definitions are intended to provide urgent measures in case of a mass influx to the people who may possibly fall into the scope of the 1951 Convention for the normalisation of the circumstance at least until the end of danger and threat towards their life and human dignity. In this sense, these regulations are not able to cover new threats not mentioned in the 1951 Convention towards people under the influence of climate change and victims of probable environmental disasters. According to the UNHCR Executive Committee; 'the asylum seekers forming part of these large-scale influxes include persons who are refugees within the meaning of the 1951 United Nations Convention and the 1967 Protocol relating to the Status of Refugees or who, owing to external aggression, occupation, foreign domination or events seriously disturbing public order in either part of, or the whole of their country of origin or nationality are compelled to seek refuge outside that country' (UNHCR, (1981). On the other hand, the UNHCR recognizes the risk of displacement due to climate change and calls all concerned parties to work together and cooperate for the available responses to climate-related displacement which "need to be guided by the fundamental principles of humanity, human dignity, human rights and international cooperation' (UNHCR, 2011b).

LFIP Art 91/1 describes temporary protection as follows; 'temporary protection may be provided for foreigners who have been forced to leave their country, cannot return to the country that they have left, and have arrived at or crossed the borders of Turkey in a mass influx situation seeking immediate and temporary protection'. TPR subsequently defines its objective in Art 1 as:

'To determine the procedures and principles pertaining to temporary protection proceedings that may be provided to foreigners, who were forced to leave their countries and are unable to return to the countries they left and arrived at or crossed our borders in masses to seek urgent and temporary protection and whose international protection requests cannot be taken under individual assessment; to determine proceedings to be carried out related to their reception to Turkey, their stay in Turkey, their rights and obligations and their exits from Turkey, to regulate the measures to be taken against 
mass movements, and the provisions related to the cooperation between national and international organizations'.

In the words of Turkish legislation on temporary protection, the scope of the reasons and circumstances, which may force people to leave their home country in mass and seek an urgent protection, is open-ended. In this sense, environmental or natural disasters and other reasons may be considered a valid and legitimate reason for a mass influx of migrants to arrive or cross Turkish border. The authority to decide whether a mass influx situation necessitates urgent protection and announce a decision of temporary protection belongs to the Council of Ministers upon the proposal of the Ministry of Interior Affairs (TPR Art 9). Accordingly, the Council of Ministers has the authority to make decision on persons who will be covered under temporary protection as well as the commencement, duration, extension or termination of temporary protection (TPR Art 10). Turkish legislation does not refer to an international call for declaration of temporary protection, however, LFIP Art 92 allows the Ministry of Internal Affairs to cooperate with the UNHCR, the International Organisation for Migration, other international organisations and non-governmental organisation for issues related to the procedures and implementation of temporary protection. On the other hand, temporary protection shall not be granted or shall be cancelled with respect to the same reasons as exclusion from international protection (TPR Art 8): If a person who benefits from temporary protection, leaves Turkey in his/her own will, avails the protection of a third country, is admitted to a third country under humanitarian reasons or resettlement, and is deceased (TPR Art 12). Art 5/1 of the TPR provides non-punishment of illegal entry and stay in case of a mass influx taken under temporary protection by the Council of Ministers.

\subsection{Obligations of the host States towards Persons under Temporary Protection}

Temporary protection procedures are naturally different from individual international protection procedures. In this respect, a host country is allowed to take some inevitable measures and limitations on the rights and freedoms of asylum seekers in mass as long as the situation necessitates. It is necessary to ensure the order and security in the borders where asylum seeker foreigners arrive in the country. Eventually, documentation of all persons may take time. It is also compulsory to separate members of armed forces from civilians. In order to accomplish the necessary entrance procedures asylum seekers may be detained in determined places for a limited time. Ultimately, demographic and economic features as well as national security, public order and public health considerations of a host country may impose some regulation and limitation in the settlement of high number of asylum seekers. However, the measures and limitations shall not be arbitrary but in conformity with justifiable reasons without infringing the essence of the fundamental rights and freedoms. As there are no universal standards of temporary protection yet and temporary protection regime may vary in different countries or contexts, the content and procedures of temporary regimes also may be inconsistent. The UNHCR Guideline requires that TPSA's shall envisage some minimum treatment standards in line with international human rights developments which also guarantee rights and freedoms envisaged for the survival of a refugee in a humane condition such as freedom from discrimination, prohibition of degrading treatment, housing, fundamental 
education, access to health and other basic services as well as self-sufficiency and work opportunities (Guideline 16).

EC Directive enumerates the obligations of the Member States towards persons enjoying temporary protection. Beside others, EC Directive guarantees freedom from discrimination (Preamble), fundamental human rights (Art 3), right of residence permit (Art 8), right to self-employment or opportunity to work, and access to social security (Art 12), right to housing (Art 13), and fundamental education (Art 14).

ECHR provides that the States shall recognize and secure the rights and freedoms enumerated in the Convention to all individuals within the jurisdiction regardless their citizenship, nationality or legal status. Furthermore, the jurisdiction of the ECtHR underlines especially some rights for the asylum seekers such as, among others, the right to marry ${ }^{23}$ and family reunification ${ }^{24}$, employment ${ }^{25}$, education ${ }^{26}$, housing ${ }^{27}$, healthcare ${ }^{28}$, social security and social assistance ${ }^{29}$ to restrain the States to differentiate between their nationals and asylum seekers, and to allow the asylum seekers to survive and maintain their economic and social existence.

\subsection{Implementation of the Obligations in Turkey and Rights of Asylum seekers under Temporary Protection}

TPR provides persons under temporary protection with right to health, education, stay in the country, accommodation, access to labour market, social assistance, interpretation and similar services (Art 26 - 32) which covers main obligations of host States as

\footnotetext{
${ }^{23}$ Among others see O'Donoghue and Others v. the UK, Application no. 34848/07, Judgement of 14 December 2010; Schembri v. Malta, Application no. 66297/13, Judgement of 19 September 2017.

${ }^{24}$ Among others see Darren Omoregie and Others v. Norway, Application no. 265/07, Judgement of 31 July 2008; Nunez v. Norway, Application no. 55597/09, Judgement of 28 June 2011.

${ }^{25}$ See Demir and Baykara v. Turkey [GC], Application no. 34503/97, Judgement of 12 November 2008, paras. 85-86.

${ }_{26}$ Among others see Timishev v. Russia, Application nos. 55762/00 and 55974/00, Judgement of 13 December 2005, para. 64; Ponomaryovi v. Bulgaria, Application no. 5335/05, Judgement of 21 June 2011, paras. 59-63.

${ }^{27}$ Among others see Gillow v. the UK, Application no. 9063/80, Judgement of 24 November 1986, paras. 55-58; N.T.P. and Others v. France, Application no. 68862/13, Judgement of 24 August 2018, paras. 46-49; M.S.S. v. Belgium and Greece, Application no. 30696/09, Judgement of 21 January 2011; N.H. and Others v. France, Application nos. 28820/13, 75547/13 and 13114/15, Judgement of 2 July 2020; Bah v. the UK, Application no. 56328/07, Judgement of 27 September 2011.

${ }^{28}$ Among others see Bensaid v. the UK, Application no. 44599/98, Judgement of 6 February 2001; Powell v. the UK (dec.), Application no. 45305/99, 4 May 2000; Lopes de Sousa Fernandes v. Portugal [GC], Application no. 56080/13, Judgement of 19 December 2017, para. 186.

${ }^{29}$ Among others see Luczak v. Poland, Application no. 77782/01, Judgement of 27 November 2007; Fawsie v. Greece, Application no. 40080/07, Judgement of 28 October 2010; Koua Poirrez v. France, Application no. 40892/98, Judgement of 30 September 2003, para. 41; Dhahbi v. Italy, Application no. 17120/09, Judgement of 8 April 2014; Gaygusuz v. Austria, Application no. 17371/90, Judgement of 16 September 1996, paras. 46-50; Koua Poirrez v. France, Application no. 40892/98, Judgement of 30 September 2003, para. 41; Andrejeva v. Latvia [GC], Application no. 55707/00, Judgement of 18 February 2009, para. 91.
} 
mentioned above. In this framework, most of the works are executed in cooperation with the UNHCR and other international charity organisations. Art 27 provides that persons under temporary protection shall apply to Ministry of Labour and Social Security for a permit to work. Turkey have not applied special requirements for foreigners in the access to labour market and granted required employment permissions to Syrian immigrants. In this regard, Turkey have adopted a self-regulating approach in labour market for immigrants and avoided a potential social and economic crisis (Akcicek, 2015).

Health Care: Art 27 of the TPR provides the health services for asylum seekers under temporary protection status. Asylum seekers are entitled to all basic health services received by Turkish citizens. Health services provided to asylum seekers in Turkey are carried out by the Ministry of Health inside or outside temporary accommodation centres. The TPR requires the Ministry of Health to establish a sufficient number of health centres, and to provide enough medical personnel and ambulances in the established health centres. The Ministry has reinforced the equipment and personnel accordingly (Önder, 2019, p. 141). However, it is often reported that health services for Syrian asylum-seekers have often fallen short due to insufficient number of health personnel and language, and cultural differences (Yavuz, 2015, p. 269). On the other hand, another shortage for the access to health services for the Syrian asylum seekers is that they must pay a "contribution fee" for the health care as all Turkish citizens, except for patients in emergency situations. Since the persons under temporary protection status have come from other countries, thus necessary screenings and vaccinations are carried out considering infectious diseases.

The legislation also requires that the environmental conditions in which the temporary accommodations for asylum seekers are located shall be made suitable for health. Within the scope of Art 27/5 of the TPR, it is assured that "Psycho-social services to be provided for persons benefiting from temporary protection shall be carried out [in cooperation] with support-solution partners, which are also specified in the Disaster Intervention Plan of Turkey published by the Ministry of Family and Social Policies".

Education Services: Education services for the Syrian asylum seekers under temporary protection status are provided by the Ministry of National Education in or out of temporary accommodation centres. Art 28 of the TPR provides regulations regarding education services. Accordingly, preschool education, primary, secondary education and trainings are given to children. Children of all ages who wish shall have access to courses such as obtaining professions and learning foreign languages. The higher education to be given outside the specified trainings are determined by the Presidency of the Council of Higher Education. According to Art 28/3 of the TPR, an asylum seeker who "has received education under a different curriculum which was documented, these documents shall be evaluated by relevant units of the Ministry of National Education or Presidency of Council of Higher Education and equivalence proceedings shall be conducted for the grades deemed appropriate". Thus, asylum seekers who gain equivalence have the right to perform their profession.

Access to the Job Market: Under Art 29 of the TPR, the right to employment given to asylum seekers under temporary protection shall be determined by the Government 
upon the proposal and opinion of Ministry of Labour and Social Security (MLSS). The persons benefiting temporary protection status shall apply to the MLSS with their temporary protection certificates and receive a work permit. The right to employment for asylum seekers under temporary protection status includes paid works as well as to work as self-employed. While their employment, persons under temporary protection shall enjoy ordinary social security facilities. Despite the numerous projects for the employment of the Syrian asylum seekers, unfortunately it is often reported that most of them are urged to work unrecorded, without social security and job security as a source of cheap employment.

Social Assistance and Services: Art 30 of the TPR contains regulations regarding social assistance and services for the people under temporary protection. According to Art 30/1 of the TPR, asylum seekers under temporary protection who are in need may have access to social assistances. Social benefits for asylum seekers are carried out by the Ministry of Family and Social Policies. In this regard, The EU is the leading donor in the international response to the Syrian crisis, with an overall total of $€ 10.9$ billion from the EU budget (DEUT, 2021).

Family reunion: Under Art 49 of the TPR, asylum seekers under temporary protection may apply for family reunification in Turkey to reunify with his or her spouse, children who have not attained maturity and dependent children, who are in another country. These applications are evaluated by the TDGMM and necessary actions may be carried out in cooperation with relevant public institutions and organizations, international organizations, and civil society organizations. In relation to minors who are found unaccompanied, the process of family reunification is initiated immediately without waiting for the children's request.

On the other hand, officials from non-governmental organizations that conduct field works with Syrian LGBTI people report that the mechanisms for preventing and protecting violence against migrants are inadequate, and almost non-existent when LGBTI people are concerned. They underline that especially the problem of employment and housing is a priority for those people. According to many sources, it is reported that LGBTI people have no or little access to family-oriented assistances and supports for migrants (DW, 2021).

Right to Nationality and Right to Property: The UNHCR Guideline underlines that TPSA's are complementary tools to international protection and shall not obstacle the rights of an asylum seeker. EC Directive, in its turn, provides in Art 18 that; 'persons enjoying temporary protection must be able to lodge an application for asylum at any time'. However, the TPR states that individual international protection applications filed by persons under the scope of temporary protection shall not be processed during the period of the implementation of temporary protection. It is especially affecting and cut off the right to citizenship. Art 11/b of Turkish Citizenship Law (TCL) ${ }^{30}$ requires a foreigner to stay

\footnotetext{
${ }^{30}$ Law no 5901 dated 29 May 2009, OG no 27256 dated 12 June 2009.
} 
minimum 5 years without interruption to file an application for citizenship. However, Art 16 of the TCL on the acquisition of Turkish nationality by having been married with a Turkish national at least for 3 years is applicable to those persons under temporary protection regime. The blockade before the right of citizenship also affects the right of acquiring property for Syrians because of so-called 'Law of Reciprocity' ${ }^{31}$ of 1927 where the acquisition of immovable in Turkey was prohibited to the nationals of Albania, Lebanon, Syria, Bulgaria and Greece. However, making long-term contracts for rent a house is possible.

Despite many available legislations and regulations as well as implementation of many projects, surveys show that Syrian asylum seekers under temporary protection in Turkey still suffer mostly from language problem, access to fundamental needs and unemployment (Ates and Bektas, 2016, p. 30-31; Yilmaz, Azer and Zenginkuzucu, 2019, p. 60).

\subsection{Non-refoulement}

The principle of 'non-refoulement' is another main pillar of international refugee and humanitarian law. The UNHCR Guideline highlighters that TPSA is 'a form of protection that provides immediate protection from refoulement and basic minimum treatment'. In a particular situation triggering a mass influx towards its borders, the host country is required to permit entry of affected populations to its territory, providing them access to territory and protection from refoulement.

Art 3 of the EC Directive provides that 'Member States shall apply temporary protection with due respect for human rights and fundamental freedoms and their obligations regarding non-refoulement'.

Art 6/1 of the TPR reaffirm the principle of non-refoulement in the context of refugees as follows;

'No one within the scope of this Regulation shall be returned to a place where he or she may be subjected to torture, inhuman or degrading punishment or treatment or, where his/her life or freedom would be threatened on account of his/her race, religion, nationality, membership of a particular social group or political opinion'.

In this respect, the well-established universal principle of 'non-refoulement' is reaffirmed in the cadre of temporary protection. On the other hand, although the scope of temporary protection in TPR exceeds the definition of a 'refugee', in this expression the principle of 'non-refoulement' covers only the persons under the threat of 'five sins'.

\subsection{Termination of Temporary Protection}

The UNHCR Guideline requires that a decision of termination of TPSA shall be taken upon the determination based on an objective assessment based on clear indications

\footnotetext{
${ }^{31}$ Law no 1062 dated 28 May 1927, OG no 608 dated 15 June 1927.
} 
that the situation causing the displacement has ended, and voluntary return is reasonable and can be carried out in safety and dignity (Guideline 21/i) except another international protection status has been granted to the individuals under temporary protection. It is recommended to take such a decision of termination collectively and in cooperation with all relevant States (Guideline 22) and the UNHCR, as well as, when appropriate, other relevant international organizations.to prevent onward movements caused by the premature ending of stay in one country. According to the EU Directive Art 6/1b, temporary protection may be terminated by a decision of the Council taken with a qualified majority, but the maximum duration shall be one year except special situations (Art 4/1). On the other hand, persons enjoying temporary protection must be able to lodge an application for asylum at any time (EU Directive Art 17/1). Art 6/2 of the EU Directive provides that the Council decision shall be based on the establishment of the fact that the situation in the country of origin is such as to permit the safe and durable return of those granted temporary protection with due respect for human rights and fundamental freedoms. In all cases, the return of those persons shall be voluntary, and the protection shall be extended until the date of return.

For the termination and cessation of the temporary protection and return of asylum seekers to their motherland, both Guideline and EU Directive requires an objective and subjective criteria. First, the situation at the origin shall be safe and available for a return with due respect for human dignity, and it is required that this assessment shall be made in cooperation with all relevant States and international organizations. ECtHR also considered the evolving overall conditions in the country and examined the countryrelated risk factors that could affect the individuals at the proposed time of removal. ${ }^{32}$ Secondly the asylum seeker shall feel him/herself safe enough for a voluntary return.

Art 11 of the TPR provides that the Minister of Interior Affairs may recommend the termination of temporary protection regime at any time. The Head of Republic is entitled to decide the termination of temporary protection regime with a Decree. The Head of Republic is not obliged to but may refer the situation to the consultations of other States or international organizations. Neither LFIP nor TPR contain objective criteria for the termination of the international protection. Furthermore, there is no requirement to take the voluntariness of the asylum seeker into consideration. In the Decree of Termination, the Head of Republic may also decide:

a) To fully suspend the temporary protection and to return of persons benefiting from temporary protection to their countries;

b) To collectively grant the status, the conditions of which are satisfied by persons benefiting from temporary protection, or to assess the applications of those who applied for international protection on an individual basis;

c) To allow persons benefiting from temporary protection to stay in Turkey subject to conditions to be determined within the scope of the Law.

\footnotetext{
${ }^{32}$ Vilvarajah and Others $v$. the UK, Application nos. 13163/87 and 4 others, judgement of 30 October 1991; N.A. v. the UK, Application no. 25904/07, judgement of 17 July 2008.
} 
With respect to Syrian asylum seekers, refugee status is not possible under LFIP. In this regard, some possibilities after the termination decision may be cited as follows:

- A collective expulsion;

- To grant citizenship to some or all the asylum seekers under TCL Art 12;

- To grant conditional refugee or subsidiary protection until their removal to a third country under LFIP Art 62 and 63.

- Allow some or all asylum seekers to stay in Turkey as foreigners;

- To make a special regulation for Syrian asylum seekers.

\section{Conclusion}

In the first half of the last century, the horrendous armed conflicts and political polarizations as Cold War made the foundation of on an international protection regime for refugees that the efforts had been already initiated even more urgent and inevitable. The UN upon the emergence of such a necessity has established the office of UNHCR. The 1951 Convention consolidated previous developments in international arena on the establishment of international refugee law and embodied a comprehensive codification of internationally recognized principles on the protection of refugees. However, as a post-World War II instrument, the scope of the 1951 Convention was limited to persons fleeing the events before 1 January 1951 and had a geographical limitation option. The 1967 Protocol, on the other hand, removed temporal and geographical limitations except already done declarations.

The 1951 Convention and the essentials of the contemporary international refugee law have three pillars. First, the definition of 'refugee' who is a person who left his or her home country and unable or unwilling to return owing to a well-founded fear of persecuted for so-called 'five sins', more concretely race, religion, nationality, membership to a social group and political opinion. Second, negative protection of the fundamental rights and freedoms of the refugee, which, in principle, shall be as broad as possible but not less than aliens lawfully staying in in the host country. In some categories of rights and freedoms, the 1951 Convention requires the host country to equip refugee with the same treatment as a national. These categories represent the rights and freedoms, which are specifically compulsory to survive in honourable and human conditions such as prohibition of discrimination, freedom of religion, access to justice, right to work and have a gainful employment and social security. The final pillar is the principal of 'non-refoulement' empowered by international human rights law, that is the prohibition of expelling or returning of a refugee to a territory where his life or freedom would be threatened on account of his race, religion, nationality, membership of a particular social group or political opinion. The principle of 'non-refoulement' in the 1951 Convention has some restrictions such as a refugee may not claim of 'nonrefoulement' when the host country considers him or her as a danger for the security of the country, in case of, for example, a conviction of a serious crime. However, the core international human rights instruments such as ECHR and the UN International Covenant on Civil and Political Rights contain a prohibition of derogation for the 
essential rights and freedoms such as right to life, prohibition of torture and degrading treatment in all cases. In this respect, the principle of 'non-refoulement' in the 1951 Convention is broadened in general and a refugee shall not be subject to deportation in all circumstances to a country where he or she is in danger of execution or torture and degrading treatment.

However, we have faced to many regrettable development and unfortunate events since 1960's and consequential mass influx paralysed individual application of refugee law to the asylum seeker victims. There are two main reasons of non-applicability of international refugee regime in such cases; one is international refugee law does not contain the categories other than 'five sins' like climate change and environmental disasters, and second is the impossibility of host State to take necessary actions under refugee law towards the urgency and complexity of the situation. Temporary protection regime has been a response to similar circumstances. However, temporary protection regime has not a common understanding and depends to the individual regulations of the States. In this context, some efforts for the establishment of international common standards for temporary protection regimes have been observed since the beginning of 2000's. The EC Directive of 2001 and the UNHCR Guideline for TPSA's of 2014 are the most common ones. Turkey adopted an international protection regime in LFIP of 2013, which also contains a temporary protection regime (Art 91) and adopted the principles and procedures of its temporary protection regime in TPR of 2014.

Temporary protection regime is a complementary to international protection aiming at filling the gaps due to mass influx and urgency of the circumstances. It shall be solution-oriented and not intended to replace international law on refugees and international protection. In this respect, a temporary protection regime shall cover three pillars of international protection law as much as possible with two exception:

Negative exception; a temporary protection regime may contain some limitation especially due to the national security and order, demographic and economic environment of the host country and other similar reasons.

Positive exception; it is expected that temporary protection should fill the gaps of international refugee law, so it shall expand the definition of people eligible for international protection such as those forced to flee from their home country due to environmental disasters.

Turkey reviewed and adopted its legislation on international protection and temporary protection after mass influx from Syria, which resulted with hosting more than 3.5 million asylum seekers in the country. Turkish legislation covers and fulfils, in general, three pillars of international protection law. However, suspension of international protection procedures during temporary protection and insufficiency on naturalization of persons under temporary protection are the main basic points to be improved. In this respect, it is necessary to take a modification on Art 16 of the TPR into consideration in line with international developments on international treatment principles under temporary protection. It is expected that Turkey would amend Art 16 pursuant the EC Directive Art 
$3 / 1$ as temporary protection shall not prejudge recognition of refugee status under the 1951 Convention.

Furthermore, today's international environment is quite different from that of the period of foundation of Turkey. In this respect, Turkey shall revise its so-called 'Law of Reciprocity' of 1927, as much as possible in negotiations with the corresponding countries and shall abolish or revise this Law consisting of 4 articles.

Finally, even if Turkish Constitution adopted a monist approach in case of protection of fundamental human rights and the 1951 Convention prevails in case of a gap or contradiction in domestic law -which does not exist in fact- it will be more appropriate that LFIP codifies literally the rights and freedoms of refugees, which shall be equal to a national such as freedom from discrimination, freedom of religion, intellectual property rights, right to fundamental education and other special regulations such as exception from prosecution for unlawful entrance, transfer of assets for refugees as recognised in the 1951 Convention.

In this framework, some recommendations for the improvement in Turkish legislation on international protection and temporary protection regarding the UNHCR Guideline, the EU Directive as well as international human rights law, may be specified as follows:

- The withdrawal of Turkey's geographical reservation to the 1951 Convention;

- The content of the rights and freedoms recognized in the TPR shall be extended to cover all the international protection law;

- The 1927 'Law of Reciprocity' shall be revised and the right to property of the Syrian asylum seekers under temporary protection shall be provided;

- Individual applications for a relevant international protection status shall be allowed to persons under temporary protection;

- Naturalization procedures shall be established and application for citizenship shall be allowed for persons under temporary protection;

- The conditions for the termination of temporary protection shall be clearly fixed in the laws and regulations, especially the determination of the availability of the situation shall be assessed in cooperation with the UNHCR and other concerned international organizations;

- After the termination of temporary protection, the asylum seekers shall not be forced for return without their will and regardless their feelings to be still under threat based on reasonable concerns.

\section{REFERENCES}

ACIKGOZ, M. \& ANIKER, H.O. (2014). Turkey's new law on foreigners and international protection: An introduction. Briefing Paper, no 2. Oxford: Turkish Migration Study Groups. [online]. Available at: https://www.compas.ox.ac.uk/2014/turkeys-newlaw-on-foreigners [Accessed: 17 November 2020]. 
AGAMBEN, G. (1998). Homo Sacer-Sovereign Power and Bare Life. Aundt: Meridian

AKCICEK, A. (2015). "Turkiye'de Suriyelilerin Toplumsal ve Ekonomik Uyumu". Liberal Düşünce (80) 51-61.

ALLAIN, J. (2001). "The Jus cogens Nature of Non-Refoulement". International Journal of Refugee Law, 13(4), pp. 533-58. https://doi.org/10.1093/ijrl/13.4.533

ARENDT, H. (1976). The origins of totalitarianism. San Diego: Harvest Books.

ASYLUM INFORMATION DATABASE [AIDA] (2020, January 17). Content of International Protection-Turkey. [online]. Available at: https://www. asylumineurope.org/reports/country/turkey/content-international-protection [Accessed: 17 November 2020].

ATES, H. and BEKTAS, M. (2016). "Suriyelilerin Toplumsal, Kültürel ve Ekonomik Entegrasyonu". Y. Deniz and F. Bilgin (Eds), Uluslararası Sosyal Bilimler Sempozyumu (26-27 Ekim 2016) (pp. 17-43). Bursa: TESAM.

BLACK, R. (2001). Environmental Refugees: Myth or Reality. [online]. Available at: http://www.unhcr.org/research/working/3ae6a0d00/environmental-refugeesmyth-reality-richard-black.html [Accessed: 21 November 2020].

BRUIN, R., \& WOUTERS, K. (2003). "Terrorism and the Non-derogability of Nonrefoulement". IJRL, 15(1), pp. 5 - 29. https://doi.org/10.1093/ijrl/15.1.5

CHIMNI, B. (2000). Globalisation, humanitarianism and the erosion of refugee protection. Working Paper, no 3, Refugee Studies Center: Oxford. https://doi.org/10.1093/ jrs/13.3.243

COSTEllo, C. \& FOSTER, M. (2016). "Non-refoulement as Custom and Jus Cogens? Putting the Prohibition to the Test". In: Heijer M., van der Wilt H. (eds) Netherlands Yearbook of International Law, vol 46. T.M.C. Asser Press, The Hague, pp. 273327. https://doi.org/10.1007/978-94-6265-114-2_10

DALKIRAN. M. (2016). Law on Foreigners and International Protection: A Real Shift in Turkey's Migration Policy, Expert Brief Regional Politics. Istanbul: AlSharq Forum. [online]. Available at: https://www.sharqforum.org/2016/05/31/law-onforeigners-and-international-protection-a-real-shift-in-turkeys-migration-policy [Accessed: 27 November 2020].

DARDAGAN KIBAR, E. (2013). "An Overview and Discussion of the New Turkish Law on Foreigners and International Protection". Perceptions Journal of International Affairs 18(3), pp. 109-128.

DELEGATION OF THE EUPEAN UNION TO TURKEY [DEUT] (2021). The EU Response to the Refugee Crisis in Turkey. Available at: https://www.avrupa.info. tr/en/eu-response-refugee-crisis-turkey-710 [Accessed 19 March 2021].

DEUTSCHE WELL [DW] (2021). “Türkiye'de iki ayrı hayat yaşıyorlar”. Available at: https://www.dw.com/tr/t\%C3\%BCrkiyede-iki-ayr\%C4\%B1-hayat-ya\%C5\%9F\% C4\%B1yorlar/a-41837359 [Accessed 19 March 2021]. 
DUGARD, J. \& VAN DEN WYNGAERT, C. (1998). "Reconciling Extradition with Human Rights". AJIL, 92(2), pp. 187 - 212. https://doi.org/10.2307/2998029

EDWARDS, A. (2012). “Temporary protection, derogation and the 1951 Refugee Convention”. Melbourne Journal of International Law, 13(2) 595-635.

EUROPEAN COMMISSION [EC] (2013a). "Common European Asylum System". Available at: https://ec.europa.eu/home-affairs/what-we-do/policies/asylum_en [Accessed 18 March 2021].

EUROPEAN COMMISSION [EC] (2013b). “Turkey 2013 Progress Report”. $\operatorname{COM}(2013) 700$ final. 16.10.2013. Available at: https://ec.europa.eu/ neighbourhood-enlargement/sites/default/files/pdf/key_documents/2013/package/ tr_rapport_2013_en.pdf [Accessed 18 March 2021].

EUROPEAN UNION [EU] (2020). Handbook on European Law relating to Asylum, Borders and Immigration. Luxembourg: EU. Available at: https://www.echr.coe. int/Documents/Handbook_asylum_ENG.pdf [Accessed 19 March 2021].

FITZPATRICK, J. (2000). "Temporary protection of refugees: Elements of a formalized regime". American Journal of International Law, 94(2), pp. 279-306. https://doi. org/10.2307/2555293

FITZPATRICK, J. \& BONOAN, R. (2003). "Cessation of Refugee Protection". In E. Feller, V. Türk, \& F. Nicholson (Eds.), Refugee Protection in International Law: UNHCR's Global Consultations on International Protection (pp. 491-544). Cambridge: CUP. https://doi.org/10.1017/CBO9780511493973.026

GOODWIN-GILL, G. \& MCADAM, J. (2007). The Refugee in International Law. Oxford: OUP.

HATHAWAY, J. (2001). “Temporary protection of refugees: Threat or solution". In J. Handmaker, \& et. al. (Eds.), Perspective on Refugee Protection in South Africa (pp. 41-49). Pretoria: Lawyers for Human Rights.

HATHAWAY, J. (2005). The Rights of Refugees under International Law. Cambridge: CUP. https://doi.org/10.1017/CBO9780511614859

INELI-CIGER, M. (2014). "Implications of the New Turkish Law on Foreigners and International Protection and Regulation no. 29153 on Temporary protection for Syrians Seeking Protection in Turkey". Oxford Monitor of Forced Immigration, 4(2), pp. 28-36.

LAUTERPACHT, E. \& BETHLEHEM, D. (2003). "The scope and content of the principle of non-refoulement: Opinion”. In E. Feller, V. Türk, \& F. Nicholson (Eds.), Refugee Protection in International Law: UNHCR's Global Consultations on International Protection (pp. 87 - 177). Cambridge: CUP. https://doi.org/10.1017/ CBO9780511493973.008

MANSOURI, F., LEACH, M., \& NETHERY, A. (2009). “Temporary protection and the Refugee Convention in Australia, Denmark and Germany". Refuge, 26(1), pp. 135-147. https://doi.org/10.25071/1920-7336.30615 
ÖNDER, N. (2019). "Türkiye'de Geçici Koruma Altındaki Suriyelilere Yönelik Sağlık Politikalarının Analizi”. The Journal of Migration Studies, 5(1), pp. 110-165.

RIYANTO, S. (2010). “The Refoulement Principle and Its Relevance in the International Legal System". Indonesian Journal of International Law, 7(4), pp. 695 - 715. https://doi.org/10.1177/1468018116666153

RYGIEL, K., BABAN, F. \& SUZAN ILCAN (2016). "The Syrian Refugee Crisis: The EU-Turkey Deal and Temporary Protection”. Global Social Policy, 16(3), pp. 315320. https://doi.org/10.1177/1468018116666153

SOYKAN, C. (2012). "The New Draft Law on Foreigners and International Protection in Turkey”. Oxford Monitor of Forced Migration, 2(2), pp. 38-47.

TURKISH DIRECTORATE GENERAL OF MIGRATION MANAGEMENT [TDGMM]. (2020). "Yillara gore Gecici Koruma Kapsamindaki Suriyeliler". [online]. Available at: https://www.goc.gov.tr/gecici-koruma5638 [Accessed: 12 January 2021].

UNITED NATIONS HIGH COMMISSIONER FOR REFUGEES [UNHCR] (1951). The refugee Convention, 1951 - the travaux préparatoires analysed by a commentary by Dr. Paul Weis. [online]. Available at: http://www.unhcr.org/protection/ travaux/4ca34be29/refugee-convention-1951-travaux-preparatoires-analysedcommentary-dr-paul.html [Accessed: 17 August 2020].

UNHCR (1981). Protection of Asylum-Seekers in Situations of Large-Scale Influx No. 22 (XXXII) - 21 October 1981, No. 22 (XXXII). [online]. Available at: http://www. refworld.org/docid/3ae68c6e10.html [Accessed: 17 August 2020].

UNHCR (2000). UNHCR Summary Observations on the Commission Proposal for a Council Directive on Minimum Standards for Giving Temporary Protection in the Event of a Mass Influx (COM(2000) 303, 24 May 2000), 15 September 2000. [online]. Available at: http://www.refworld.org/docid/437c64b04.html [Accessed: 17 August 2020].

UNHCR (2011a). The 1951 Convention relating to the status of refugees and its 1967 Protocol. Geneva: UNHCR.

UNHCR (2011b). Summary of Deliberations on Climate Change and Displacement. [online]. Available at: http://www.unhcr.org/4da2b5e19.html [Accessed: 28 August 2020].

UNHCR (2014). Guidelines on temporary protection or stay arrangements. [online]. Available at: https://cms.emergency.unhcr.org/documents/11982/44933/UNHC $\mathrm{R},+$ Guidelines+on+Temporary+Protection+or+Stay+Arrangements, $+2014 / 373$ af576-cd03-4134-9d49-e03aladd6a9e [Accessed: 17 December 2020].

UNHCR (2018). UNHCR in 2018. [online]. Available at: http://reporting.unhcr.org/sites/ default/files/gr2018/pdf/01b_Mission.pdf [Accessed: 17 December 2020].

VÄRK, R. (2012). "Diplomatic asylum: Theory, Practice and the Case of Julian Assange”. Sisekaitseakadeemia Toimetised, pp. 240-259. Available at: https://www. peacepalacelibrary.nl/ebooks/files/386022364.pdf [Accessed: 18 March 2021]. 
YAVUZ, Ö. (2015). “Türkiye'de Suriyeli Mültecilere Yapılan Sağlık Yardımlarının Yasal ve Etik Temelleri”. Mustafa Kemal University Journal of Social Sciences Institute, 12(30), pp. 265-280.

YILMAZ, S., AZER, Ö.A., ZENGINKUZUCU, D. (2019). İstanbul Esenyurt İlçesi Suriyeli Siğınmacıların Sosyal ve Ekonomik Durumlart. Istanbul: Istanbul Esenyurt Universitesi.

Received: January $12^{\text {th }} 2020$

Accepted: March $24^{\text {th }} 2021$

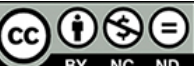

